\title{
Improving Students' Interest in Learning English by Using Games
}

\author{
Mery Silalahi ${ }^{a, 1}$ \\ a Universitas Sari Mutiara Indonesia \\ ${ }^{1}$ mery.silalahi@yahoo.com
}

\begin{abstract}
One of the teachers' efforts to improve students' interest in English is learning English through games. The learning process by playing games can provide more interactive English learning atmosphere so that it is expected to improve the ability of students in vocabulary development. Learning through games can provide several benefits. First, what is learned by students is not only in the form of mere knowledge of reason but experienced in real terms; such experiences are difficult to forget. Second, the lessons provided are pleasantly accepted, because they are related to the nature of the game which is entertaining and joyful. Thus, the possibility of student rejection of what is taught can be minimized. Third, because the game is fun, playing at the same time generates great interest for students about certain things or topics. Based on the reasons, it is expected that through these fun activities that is games; students' interest in learning English can be improved.
\end{abstract}

Keywords

Improving Students' Interest; Learning English; Using Games

\section{INTRODUCTION}

English is the language of international communication that has been used in various countries in the world as a global communication tool. In the current era of globalization, English is felt to have a significant role, so that English becomes one of the languages that must be mastered, not least in Indonesia.

The influence of globalization has made Indonesian citizens more active in learning English. The active learning is find it difficult to understand English. This inseparable from the role of schools that implement learning programs that emphasize the ability of students to master a foreign language; one of them is English. This also happens in other countries including Indonesia as a consequence of the progress of English, where governments throughout the world actively support learning English for their citizens.

However, because of the broad and complex scope of English, not a few people 
is also experienced by most students in schools. They tend to dislike learning English because it is difficult to understand. Because of that, many schools are starting to implement learning methods that can support the convenience of students in understanding or understanding English, so that in the end the English language can be one of the lessons preferred by students in schools.

One method that can be an alternative to making learning English easier and more enjoyable is by learning while playing, which is through certain games. Learning through games can provide several benefits. First, what is learned by students is not only in the form of mere knowledge of reason but experienced in real terms; such experiences are difficult to forget. Second, the lessons provided are pleasantly accepted, because they are related to the nature of the game which is entertaining and joyful. Thus, the possibility of student rejection of what is taught can be minimized. Third, because the game is fun, playing at the same time generates excellent interest for students about certain things or topics.

Well-designed games (games) will develop students' skills in certain cases. Actually, in learning languages, the principle is the application or use. And through games (games) this principle will be more effectively applied. Games are not merely synonymous with the activities of small children. The learning process while playing is also suitable for all ages because methods like this can increase the interest and motivation to learn English as well as arouse the learning atmosphere to be more interactive for all people of all ages. With games, learning English becomes more exciting, fun, and not boring. This is certainly different if you use the lecture method or discussion. Through fun activities such as games, it is hoped that it can arouse students' interest in learning English and be able to understand English quickly and easily.

\section{LITERATURE REVIEW}

Through playing, a person not only stimulates the growth of his muscles but more than that, a person uses all his emotions, his feelings, and his thoughts. Fun is one of the main elements of playing. Someone will play as long as the activity entertains him. When you are bored, someone will stop playing. Playing does not mean wasting time or being busy with his work. But through playing someone gets real-life experiences. By playing someone 
will find their strengths and weaknesses, interests, how to complete tasks in play, etc. Playing is an important element for one's development both physically, emotionally, mentally, intellectually, creatively and socially. Someone who gets enough opportunity to play will be a person who is easy to be friends, creative and smart when compared to those who have little opportunity to play.

They are learning while playing can stimulate children's growth and development. What is meant by stimulation here is stimulation that comes from the environment outside the individual. Children who get a lot of stimulation will develop faster than children who lack or don't even get stimulation. Stimulation can also function as reinforcement. Provision of stimulation will be more effective when paying attention to the needs of children by the stages of development. Here, games are a proper stimulation for children learning English.

As stated by Morley (1986) that playing is a valuable "school" for children, so that intellectual development is optimal. So, learning English while playing is expected to develop children's intellectual abilities.
The things that need to be considered in play activities are, children, need a variety of game tools, so if you are bored with one game, then you can switch to another game. Playing must also be balanced, meaning that there must be a balance between active and passive play which is usually called entertainment. Inactive play, pleasure is derived from what is done by oneself, whereas passive play means pleasure obtained from others.

1. Playing Active

a. Play using observing/investigating (Exploratory play). The child's first concern with playing tools is checking the game equipment. In this case, the child tends to pay attention to the game.

b. Play construction.

c. Play drama.

d. Play ball, rope and so on

2. Playing Passive

In this case, the child plays a passive role, among others by seeing and / hearing. This passive play is ideal if the child is tired of playing actively and needs something to overcome his boredom and fatigue, example:

a. See pictures in books/magazines.

b. Listen to stories or music.

c. Watching TV. 


\section{Identification of problems}

Based on the background of the study above, problems can be identified as the following:

1. Efforts to increase students' English. interest in learning English.

2. Efforts to improve the students' English skills through playing games. Students are expected to be able to speak English both to teachers and friends.

\section{Purpose of the Study}

1. Implementing games in learning to improve students' skills of English.

2. We are providing an experience of learning English through games to increase the students' interest in learning English.

Based on the formulation of the problem described above, it is expected that all students get the benefits of learning English by using games. In addition to eliminating boredom, games as a fun alternative learning are known to be effective in changing the monotonous learning atmosphere (lecture or discussion) to be more exciting and vibrant. The learning process by playing games can provide more interactive English learning atmosphere so that it is expected to improve the ability of students in vocabulary development. The nature of this method is also expected able to increase the students' interest in learning

\section{The Various Games}

\section{Whisper Race}

As the name implies, this game relies on memory. First, divide the students into two teams. One of the team members was given a list of words they needed to memorize. Then the list of words is whispered to the member of one other team. The last member must mention the complete list of words. The team that removes one word from the list of words that have been given is declared defeated.

Hide and Seek

This game can train the use of prepositions in English. Here is the way this game works. First, a participant was asked to leave the class while the other participants were tasked with hiding items. Then, participants who came out were asked to find the location of objects that were hidden by giving questions. 


\section{What's Missing?}

This game uses picture media in the form of a puzzle. Each participant competes to be able to guess the missing pieces of the image by submitting the appropriate answers to English grammar.

\section{Action Game}

This game relies on gestures. Select one of the participants to read a story and then try to practice each part of the word in the story that can be practiced. This type of game can also train a wealth of English vocabulary owned. For those who mistakenly practice, give a little humorous punishment.

\section{Game Market}

This type of game tests participants to be able to make good sentence compositions. Give the first sentence whose ideas lead to shopping activities on the market, for example. Note that each participant gives a sentence, whether the composition of the grammar, mastery of vocabulary and pronunciation are good. By correcting each other, we can also learn.

\section{RESULT AND DISCUSSION}

The participants who took part in this research were the grade 5th Elementary
School students of Panti Budaya Kisaran with 40 participants. The place used to conduct this training is in one of the classrooms of class 5 Elementary School students of Panti Budaya Kisaran. This research was conducted to 40 students from various classes of the grade 5th.

Games are an important component in implementing this research. The games that will be played in the classroom at the time of the research are games which are certainly considered to have significant influence to increase the interest and motivation of students to learn English.

\section{Proceed your Sentence}

The way to play this game is very easy, and specifically, this game is done to improve the listening ability of a student. This is a game where students pass on words or sentences that are whispered continuously. It is very worthy of trying at any level of education. As a teacher, we are only expected to adapt to the abilities of students at every level of education. The step to play the game is as follows:

1. Divide students into groups and each group has five members.

2. Prepare words that will be given to students in our memories. 
3. Determine the student sequence number. That is, there are first, second, third, fourth, and fifth students.

4. Speaking sentences or word phrases to the first student. But do it first in one group so that we can easily watch it.

5. Tell the first student to whisper the words we whispered to the second student, and then the second student continues to the third student, the third student to the fourth student, and the fourth student to the fifth student.

6. Instruct the fifth student to mention the whispered word and note the word.

7. Perform the procedure continues in each group. Then, the fifth student who has the words most similar to the initial words we give, then the group becomes the winner.

\section{A Creative Story}

In this game, the teacher will read a story, and then students continue it with their imagination. Students who are unable to continue the story will get the sentence. Made specifically to train a student's reasoning and speaking skills in English. Here are the steps to playing this game:

1. Prepare a marker as a tool for determining student turn.
2. Tell a popular story such as Cinderella or Pinocchio, but only the beginning part then decides the story in the desired parts.

3. Submit a marker to a student and give him instructions to keep passing the marker to his friend as we count.

4. On the fifth count, students are instructed to stop passing markers.

5. The last student who gets the marker must continue the story according to his imagination. The story he continued, of course, is not too much, which is only one long sentence.

6. We must free students to continue the story as they please and not force it to stick to the storyline.

7. After students complete the story, then counting and students who get markers on the fifth count, are instructed to continue the story.

8. Students who are not able to continue the story, and then he must be punished for singing or doing other positive things.

\section{Word Mapping}

Word mapping is a game that mentions a word; then students mention related words. For example, we mention the word house, so students look for 
derivative words that are related, namely chair, table, dining room, bathroom, and floor. Word mapping is used to increase a student's reasoning and increase the vocabulary of their vocabulary. The steps are as follows:

1. Preparing words that can provide enough derivative words such as computers, park, house, street, and many more.

2. Divide students into small groups where each group consists of 3 people.

3. Instruct students to prepare one paper, pen, and without using a dictionary.

4. Mention the words we have arranged.

5. Give each group five minutes to write as many derivative words as possible.

6. Groups that get the most words, then they win in this English game.

This activity begins with gathering students in a room. Then, the researcher gives the material which is related to the topic "Learning English through Games". This activity aims to provide theoretical and practical knowledge to the grade 5th Elementary School students of Panti Budaya Kisaran about the material to be carried out. The activities are continued to the application of games in learning English. The games are proceed with your Sentence, A Creative Story, and Word
Mapping. During the implementation, this activity is expected can make the students more quickly understand English.

Through these fun activities, students are very enthusiastic about following the step by step games procedures. Students also seemed excited and tried to answer the puzzle and guess the word. This can hone children's English skills, especially in vocabulary and grammar. Games provided will help children maintain the knowledge they have before. So, besides being far from saturation, with this activity, learning English now becomes more fun and finally can be easily understood.

\section{CONCLUSION}

The responses from the students were positive where the students felt the benefits gained after learning English by using games.

Generally, using games in learning English have many benefits; they are:

1. Increasing students' understanding of the importance of learning English.

2. Extending the students insights, especially the teachers regarding the method of learning English while playing.

3. Motivating students and teachers to apply games as a method in the class. 
Based on the notes provided by the students (attached), there are several suggestions related to the implementation of games in learning English, they are:

1. Need consistency of the games' application in learning English.

2. Focus on introducing the appropriate games in learning English that can make students easy and quick to understand English.

\section{REFERENCES}

Marheni, Adijanti. (1990). Peranan stimulasi dalam tumbuh kembang anak, Kumpulan Makalah Ceramah Berkala VIII, Lab. IImu Kesehatan Anak Fak. Kedokteran UNUD.

Oppenheim J. F. (1984). Kids and play, $1^{\text {st }}$. Ed. New York: Ballantine books.

Pedoman penggunaan Alat Permainan Edukatif (APE). (1984). Program Bina Keluarga dan Balita, Kantor Menteri Negara Urusan Peranan Wanita UNICEF.

Soetjiningsih. (1984). Alat Permainan Edukatif, Kumpulan Makalah Ceramah Berkala ke-II Laboratorium IImu Kesehatan Anak FK UNUD - ISWI (Ikatan Sarjana Wanita)-Bali.
Sularyo, Titi S. (1993). Pentingnya stimulasi dini, Seminar dan Pelatihan Sehari: Pencatatan Pemantauan tumbuh kembang anak, Lab. Ilmu Kesehatan Anak FKUI, 